\title{
Influence of Soil Characteristics and Formulation on Alachlor Dissipation in Soil
}

\section{Fátima Sopeña* \\ Celia Maqueda}

Esmeralda Morillo

Institute of Natural Resources and Agrobiology (CSIC)

Reina Mercedes, 10, Apdo. 1052

41080-Seville

Spain
Alachlor [2-chloro- $N$-(2,6-diethylphenyl)- $N$-(methoxymethyl)acetamide] is one of the most commonly found herbicides in surface and groundwaters of the United States and Europe, and it contaminates these environments even when it is used according to the manufacturer's instructions for conventional formulations. To determine how its persistence in soil is affected by herbicide formulation and soil type, alachlor was applied to several soils in different formulations: technical grade (AT), a commercial formulation (CF), and different ethylcellulose microencapsulated formulations (MEFs). The results show that MEFs provided a prolonged release of the herbicide into the soil solution and protected against its dissipation in soil more than AT or the CF. The half-life in soil $\left(t_{1 / 2}\right)$ for the AT, CF, and MEFs was up to $2.7,6.4$, and $32.54 \mathrm{~d}$, respectively. The lowest herbicide loss was observed in MEFs prepared using a lower stirring speed or a higher ethylcellulose viscosity during the microencapsulation process. As with AT and the CF, the microencapsulated alachlor persisted longer in the soils with low $\mathrm{pH}$ and high clay content. In the soil where alachlor showed the least persistence, MEFs reduced the herbicide loss by $54 \%$ compared with the CF. The use of MEFs extended the alachlor concentration in the soil, thereby avoiding the need for using high herbicide application rates and decreasing the risk of environmental contamination.

Abbreviations: $\mathrm{AT}$, alachlor technical grade; $\mathrm{CF}$, commercial formulation; $\mathrm{CRF}$, controlled release formulation; DA, dehydrogenase activity; EC, ethylcellulose; HPLC, high-performance liquid chromatography; MEFs, ethylcellulose microencapsulated formulation; PEG, polyethylene glycol; PVA, polyvinyl alcohol; TPF, 1,3,5-triphenyltetrazolium formazane; TRIS, tris(hydroxymethyl) aminomethane; TTC, 2,3,5-triphenyl-2Htetrazolium chloride.
A lachlor is an organochlorine preemergence herbicide that is used for weed control on corn (Zea mays L.), soybean [Glycine max (L.) Merr.], sorghum [Sorghum bicolor (L.) Moench], peanut (Arachis hypogaea L.), and bean (Phaseolus vulgaris L.) (USEPA, 1998). Alachlor has a molecular weight of 269.77, a water solubility of $242 \mathrm{mg} \mathrm{L}^{-1}$, and a vapor pressure of $2.13 \mathrm{mPa}$ at $25^{\circ} \mathrm{C}$ (Ahrens, 1994). It is one of the most commonly detected compounds in natural waters of the United States (Boparai et al., 2006) and Europe (Claver et al., 2006); even when applied according to directions, its use results in the contamination of surface and groundwaters (USEPA, 1998; Schwab et al., 2006; Selim et al., 2002). In light of its toxicity and its occurrence in natural waters, the USEPA has classified it as a restricted-use pesticide (USEPA, 1998). Its photodegradation and volatilization have been shown to be important for its dissipation under certain circumstances (Schwab et al., 2006; Dailey, 2004). This pesticide has moderate to high mobility in sandy and silty soils (USEPA, 1998) and based on its organic

Soil Sci. Soc. Am. J. 72:767-774

doi:10.2136/sssaj2007.0186

Received 22 May 2007.

*Corresponding author (fsopenav@irnase.csic.es).

(c) Soil Science Society of America

677 S. Segoe Rd. Madison WI 53711 USA

All rights reserved. No part of this periodical may be reproduced or transmitted in any form or by any means, electronic or mechanical, including photocopying, recording, or any information storage and retrieval system, without permission in writing from the publisher. Permission for printing and for reprinting the material contained herein has been obtained by the publisher.
C normalized distribution coefficient $\left(K_{\mathrm{oc}}\right)$ and dissipation half-life, the compound is classified as a "leacher" in most soils studied by Yen et al. (1994). Overall, the mobility and persistence of alachlor in soil are greatly influenced by environmental conditions such as soil type, temperature, moisture levels, microbial activity, $\mathrm{O}_{2}$ levels, and $\mathrm{pH}$ (Jurado-Expósito and Walker, 1998; Weed et al., 1998; Yen et al., 1994; Walker et al., 1992). The half-life of alachlor in soil ranges from 3 to 50 d (Schwab et al., 2006; Jurado-Expósito and Walker, 1998; Gerstl et al., 1998).

Controlled release formulations (CRFs) of pesticides can maintain the threshold concentration of the active ingredient at the required rate and reduce its levels in the environment because less active ingredient is needed to maintain biological efficacy (Fernández-Pérez et al., 2005; Carrizosa et al., 2003; Undabeytia et al., 2003; Vasilakoglou et al., 2001). One of the procedures used for preparing CRFs is based on microencapsulation techniques, which are reported to improve alachlor persistence in soil in most cases studied (Vasilakoglou et al., 2001; Johnson and Pepperman, 1996; Huang and Ahrens, 1991). The persistence varied greatly, however, depending on the experimental conditions, the type of technique, and the polymer used for obtaining the alachlor microsystem (Wienhold and Gish, 1994; Buhler et al., 1994; Nègre et al., 1992; Fleming et al., 1992; Riggle and Penner, 1988).

While most of the published studies addressing the influence of soil characteristics on alachlor persistence have utilized pure or commercial formulations of the compound, few studies have examined alachlor persistence in microencapsulated formulations (Nègre et al., 1992; Greene et al., 1992). Moreover, 
although the alachlor dosage recommended for early preplant ranges from 2.5 to $4.2 \mathrm{~kg}$ a.i. ha ${ }^{-1}$ (Ahrens, 1994), most of the previous studies have used initial concentrations either lower (Weed et al., 1998; Dowler et al., 1999; Mueller et al., 1999) or higher (Petersen et al., 1988; Walker et al., 1992; Nègre et al., 1992) than those normally used in field experiments.

Ethylcellulose (EC) is a hydrophobic polymer that has been used to prepare formulations of different herbicides by microencapsulation. Little information has been reported, however, about the persistence of cellulose-encapsulated herbicides in soils (Sopeña et al., 2007). Even though EC-alachlor microspheres have been shown to prolong the release of alachlor in water (Fernández-Urrusuno et al., 2000), few studies have evaluated the behavior of these microspheres in soil. Preliminary studies by Dowler et al. (1999) and Dailey (2004) evaluated the efficacy and losses by volatilization from different cellulose microcapsules. The results indicated that the total herbicide volatilization from cellulose microcapsules was lower than that of a CF (Dowler et al., 1999). The herbicidal efficacy was at least as effective as the $\mathrm{CF}$, with the best results at 10 or more wk after application of 9-mo-old formulations (Dailey, 2004). This long period of persistence represents a disadvantage if one considers that longer release periods may make more herbicide available during later leaching events and could increase carryover to subsequent crops. The effects of some preparation conditions used in the microencapsulation of this herbicide with $\mathrm{EC}$ have been previously described (Fernández-Urrusuno et al., 2000); however, the behavior of alachlor in soil from these cellulose CRFs has not yet been reported. Our study examined the influence of preparation conditions (e.g., stirring speed and the addition of pore-forming agents) and soil characteristics on alachlor dissipation in soils. The objective was to facilitate selection of the optimal conditions to avoid successive herbicide applications that could lead to environmental contamination.

\section{MATERIALS AND METHODS Materials Chemicals}

Technical-grade alachlor (Alanex Tech., 95\% pure) was purchased from Makhtesim Agan España, S.A. (Valencia, Spain); it was recrystallized twice from 96\% ethanol, as described by Dailey and Johnson (1995). The commercial formulation of alachlor (Alanex 48EC, $480 \mathrm{~g} \mathrm{~L}^{-1}$ alachlor) was kindly provided by Agan Chemicals, Ashdod, Israel. Ethylcellulose 30 to $50 \mathrm{mPa}$ (EC 40) and ethylcellulose $10 \mathrm{mPa}$ (EC 10) (both of which had 48-49.5\% [w/w] ethoxyl content) were purchased from Fluka (Buchs, Swizerland) and Dow Chemical Co. (Rotterdam, the Netherlands), respectively. Polyvinyl alcohol (PVA) with molecular weight (MW) 30,000 to 70,000 was obtained from Sigma Chemical Co. (St. Louis, MO). Acofarma (Barcelona,

Table 1. Physicochemical properties of the soils used.

\begin{tabular}{|c|c|c|c|c|c|c|c|}
\hline Soil & $\mathrm{pH}$ & $\mathrm{CaCO}_{3}$ & OMt & Sand & Silt & Clay & USDA classification¥ \\
\hline \multirow[b]{2}{*}{ Silt loam } & & $\%$ & & $-\mathrm{gk}$ & & & \multirow[b]{2}{*}{ Aquic Dystric Eutrochrept } \\
\hline & 6.0 & 0.0 & 14.1 & 167 & 586 & 247 & \\
\hline Loamy sand & 8.0 & 6.9 & 9.2 & 876 & 40 & 84 & Typic Xeropsamment \\
\hline Clay & 8.0 & 24.1 & 17.6 & 27 & 315 & 659 & Chromic Haploxerert \\
\hline Sandy loam & 8.4 & 18.2 & 12.6 & 746 & 121 & 132 & Typic Calcixerept \\
\hline
\end{tabular}

t Organic matter content.

₹ Soil Survey Staff (2006).
Spain) supplied polyethylene glycol (PEG) with MW 4000. SigmaAldrich (Madrid, Spain) supplied 2,3,5-triphenyl-2H-tetrazolium chloride (TTC), 1,3,5-triphenyltetrazolium formazane (TPF), and tris(hydroxymethyl)aminomethane (TRIS). High-performance liquid chromatography (HPLC)-grade acetronitrile, methanol, and chloroform were purchased from Merck (Darmstadt, Germany). All reagents were of analytical grade.

\section{Soils}

The soils used were all from southwestern Spain. The silt loam soil was classified as an Aquic Dystric Eutrochrept and collected near Aracena (Huelva) $\left(37^{\circ} 53^{\prime} 00^{\prime \prime} \mathrm{N}, 06^{\circ} 28^{\prime} 31^{\prime \prime} \mathrm{W}\right)$. The loamy sand and sandy loam soils, classified as a Typic Xeropsamment and a Typic Calcixerept, respectively, were obtained from the experimental farm at 'La Hampa' of Coria (Sevilla) $\left(37^{\circ} 16^{\prime} 59^{\prime \prime} \mathrm{N}, 06^{\circ} 04^{\prime} 03^{\prime \prime}\right.$ W and $37^{\circ} 17^{\prime} 05^{\prime \prime} \mathrm{N}, 06^{\circ} 05^{\prime} 10^{\prime \prime} \mathrm{W}$, respectively). The clay soil, classified as a Chromic Haploxerert, was collected from the experimental farm at 'Las Torres' of Carmona (Sevilla) (37 $\left.24^{\prime} 07^{\prime \prime} \mathrm{N}, 05^{\circ} 35^{\prime} 10^{\prime \prime} \mathrm{W}\right)$.

Samples were collected from the surface soil, at a depth of 0 to $20 \mathrm{~cm}$, and crushed to pass through a 2-mm sieve. They were analyzed for $\mathrm{pH}$, total carbonate content, particle size distribution, and organic matter content (Table 1). Particle size distribution was measured by the Bouyoucos densimeter (Gee and Bauder, 1979), organic matter by $\mathrm{K}_{2} \mathrm{Cr}_{2} \mathrm{O}_{7}$ oxidation, $\mathrm{pH}$ by testing a saturated paste, and total carbonate content by a manometric method (Demolon and Leroux, 1952).

\section{Experiments \\ Microsphere Preparation}

Using a previously described procedure (Sopeña et al., 2005), EC-alachlor formulations were prepared by the oil-in-water emulsion solvent evaporation technique, using PVA as the emulsifier and two types of EC with different viscosities $(\mathrm{EC} 10<\mathrm{EC} 40)$ as the matrix polymer. In three of the formulations, $400 \mathrm{mg}$ (40\%) of PEG (used as a channel former) was added to the organic polymer solution before the formation of emulsion with the aqueous phase. Briefly, EC (1 g) was dissolved in $15 \mathrm{~mL}$ of chloroform. Different amounts of alachlor $(0.2$ and $0.3 \mathrm{~g})$ were dissolved in this polymer solution at room temperature. The herbicide-polymer solution was then emulsified into an aqueous phase by dropwise addition into $150 \mathrm{~mL}$ of aqueous solution containing $225 \mathrm{mg}(0.15 \%)$ of PVA while stirring at either 600 or $300 \mathrm{rpm}$. All experiments were performed in triplicate. Table 2 shows the conditions used to prepare the various alachlor formulations.

\section{Water Release Studies}

Dissolution tests of alachlor in the CF and seven other formulations were performed in triplicate with a rotating paddle apparatus (Sotax). Microspheres containing $5 \mathrm{mg}$ of alachlor were added to $1000 \mathrm{~mL}$ of deionized water at $25^{\circ} \mathrm{C}$ and stirred at $50 \mathrm{rpm}$. At appropriate time intervals $(0,3$, $6,24,48,72,96$, and $100 \mathrm{~h}$ ), samples were taken and the herbicide content analyzed by HPLC.

\section{Microbiological Analysis of Soils}

Soil bioactivity was evaluated for all soils used in the dissipation experiments by measuring two parameters: soil microbial biomass $\mathrm{C}$ and dehydrogenase activity (DA).

Microbial biomass $\mathrm{C}$ was determined by the chloroform fumigation-extraction method modified by Gregorich et al. (1990). Chloroform was added directly to the soil (3 g) to lyse microbial cells. After that, a soil control (no chloroform added) 
Table 2. Conditions used in microsphere formulations.

\begin{tabular}{llccc} 
Formulation & EC/At ratio & PVA & PEG§ & Stirring speed \\
\hline With EC10 & & \multicolumn{2}{c}{$\%$} & rpm \\
A15 & 5 & 0.150 & - & 600 \\
A17 & 5 & 0.150 & 40 & 600 \\
A18 & 5 & 0.150 & 40 & 300 \\
A22 & 3.33 & 0.150 & - & 600 \\
With EC40\# & & & & \\
A4 & 5 & 0.150 & - & 600 \\
A8 & 5 & 0.150 & 40 & 600 \\
A14 & 3.33 & 0.150 & - & 600 \\
\hline
\end{tabular}

† Ethylcellulose/alachlor ratio.

‡ Polyvinyl alcohol.

$\S$ Polyethylene glycol.

I Ethylcellulose 10.

\# Ethylcellulose 40.

and samples were extracted with $0.5 \mathrm{~mol} \mathrm{~L}^{-1} \mathrm{~K}_{2} \mathrm{SO}_{4}$ and analyzed for $\mathrm{C}$ content in a $\mathrm{C}$ analyzer (Shimadzu TOC- $\mathrm{V}_{\mathrm{CSH}}$, Kyoto, Japan). Microbial biomass $\mathrm{C}$ was determined from the difference in $\mathrm{C}$ content between fumigated and control soil samples.

The DA assay was performed in triplicate after 2 wk of incubation. This enzyme is active only in living organisms and is an indicator of soil microbial activity. Soil samples $(5 \mathrm{~g})$ were incubated at $30^{\circ} \mathrm{C}$ with $5 \mathrm{~mL}$ of colorless TTC solution $(0.5 \%$ by weight $)$ in $0.1 \mathrm{~mol} \mathrm{~L}^{-1}$ TRIS buffer adjusted to $\mathrm{pH} 7.6$ with $\mathrm{HCl}$. The TTC was reduced by dehydrogenase enzymes to become red, water-insoluble TPF, which was extracted with $25 \mathrm{~mL}$ of acetone after $24 \mathrm{~h}$ of incubation. The samples were shaken for $1.0 \mathrm{~h}$ and centrifuged at $5000 \times g$ for 12 min. The intensity of the red color of the supernatant was measured by spectrophotometry at $485 \mathrm{~nm}$ and converted to bioactivity ( $\mathrm{mg}$ TPF kg-1 soil) based on a set of TPF standards.

\section{Dissipation Experiments in Soil}

Alachlor applied as AT, CF, and MEFs was tested for herbicide dissipation rate in several soils. The objective was to determine the influence of soil characteristics on the dissipation of alachlor from selected MEFs. The soils used in these dissipation experiments included loamy sand, silt loam, clay, and sandy loam. Loamy sand was the only soil used to evaluate dissipation characteristics of all the formulations. This study is significant from an agricultural perspective because it used realistic herbicide concentrations. The initial concentration for all formulations and soils was $3 \mathrm{mg}$ a.i. $\mathrm{kg}^{-1}$ soil, which corresponds to a field application rate of $3.6 \mathrm{~kg}$ a.i. $\mathrm{ha}^{-1}$, assuming that the herbicide is incorporated into the top $10 \mathrm{~cm}$ of a soil with an average bulk density of $1200 \mathrm{~kg} \mathrm{~m}^{-3}$.

Air-dried soil $(200 \mathrm{~g})$ was mixed in triplicate with $0.6 \mathrm{mg}$ of alachlor $\left(3 \mathrm{mg} \mathrm{kg}^{-1}\right.$ soil) and then shaken thoroughly for $24 \mathrm{~h}$. After mixing, the samples were transferred to plastic pots, covered with aluminum foil, and incubated in the dark for $2 \mathrm{wk}$ at $25^{\circ} \mathrm{C}$. The soil moisture content was maintained at field capacity by periodic additions of water. Quadruplicate soil samples (2 $\mathrm{g}$ each) were taken daily after treatment and stored at $-20^{\circ} \mathrm{C}$ until analysis. Before sampling, the soil was thoroughly mixed. Alachlor was then extracted from the soil samples with methanol and analyzed by HPLC. The dissipation of alachlor in soil was described by the first-order equation (Guo and Wagenet, 1999)

$$
\ln C=\ln C_{\mathrm{o}}-K t
$$

where $C$ is the herbicide concentration in the soil at time $t, C_{\mathrm{o}}$ is the initial herbicide concentration in the soil, and $K$ is the dissipation rate
Table 3. Alachlor degraded after $14 \mathrm{~d}$, predicted half-life $\left(t_{1 / 2}\right)$ values ( \pm standard error), degradation constants $(K)$, and coefficients of determination $\left(r^{2}\right)$ for the regressions showing alachlor dissipation in loamy sand soil treated with technical-grade alachlor (AT), a commercial formulation (CF), and ethylcellulose formulations (A4-A22).

\begin{tabular}{lcccc} 
Formulation & $\boldsymbol{t}_{\mathbf{1 / 2}}$ & $\boldsymbol{K}$ & $\boldsymbol{r}^{\mathbf{2}}$ & Alachlor degraded \\
\hline & $\mathrm{d}$ & $\mathrm{d}^{-1}$ & & $\%$ \\
AT & $2.68 \pm 0.04$ & 0.258 & 0.99 & 96.8 \\
CF & $6.41 \pm 0.10$ & 0.108 & 0.95 & 85.0 \\
A8 & $9.53 \pm 0.12$ & 0.073 & 0.96 & 67.1 \\
A22 & $11.24 \pm 0.17$ & 0.062 & 0.93 & 61.4 \\
A17 & $11.44 \pm 0.22$ & 0.061 & 0.97 & 59.5 \\
A15 & $13.79 \pm 0.08$ & 0.050 & 0.99 & 51.1 \\
A14 & $14.86 \pm 0.09$ & 0.047 & 0.98 & 47.8 \\
A18 & $15.78 \pm 0.07$ & 0.044 & 0.99 & 38.6 \\
A4 & $32.54 \pm 0.04$ & 0.021 & 0.99 & 25.8 \\
\hline
\end{tabular}

constant. The time required to reach an alachlor dissipation of $50 \%$ is the half-life $\left(t_{1 / 2}\right)$, which, in first-order kinetics, is defined as

$$
t_{1 / 2}=0.6932 / \mathrm{K}
$$

\section{Analytical Methods \\ Alachlor Extraction}

The soil ( $2 \mathrm{~g}$ ) was blended with anhydrous $\mathrm{Na}_{2} \mathrm{SO}_{4}(3 \mathrm{~g})$ and pulverized in an agate mortar to eliminate aggregates and to remove residual water. The herbicide residues in the soil were shaken twice with methanol $(20 \mathrm{~mL})$ for $24 \mathrm{~h}$ at $20 \pm 1^{\circ} \mathrm{C}$. The extraction efficiency of the method was $98.5 \pm$ $1.5 \%$. Alachlor extraction was performed in triplicate.

\section{High-Performance Liquid Chromatography Analysis}

Alachlor samples were analyzed by HPLC under the following conditions: mobile phase, 60:40 acetonitrile/water; flow, $1 \mathrm{~mL} \mathrm{~min}^{-1}$; chromatographic column, Kromasil C18 (15 × 0.40 i.d.) (Teknokroma, Spain); diode array detector (Shimadzu SPD-M10AVP) at a wavelength of $220 \mathrm{~nm}$. The retention time for alachlor under these conditions was approximately $6.5 \mathrm{~min}$. The limit of detection was $0.01 \mathrm{mg} \mathrm{L}^{-1}$.

\section{RESULTS AND DISCUSSION}

\section{Influence of Formulation on Alachlor Dissipation in Soil}

Alachlor degradation in the loamy sand soil followed firstorder kinetics, with coefficients of determination $\left(r^{2}\right)$ ranging from 0.93 to 0.99 (Table 3 ). Half-life $\left(t_{1 / 2}\right)$ and $K$ values for the soils samples for each formulation are also shown in Table 3. The $t_{1 / 2}$ values for the AT and CF were 2.68 and $6.41 \mathrm{~d}$, respectively; however, the $t_{1 / 2}$ for the MEFs was much longer, ranging from 9.53 to $32.54 \mathrm{~d}$.

Figures 1, 2, and 3 show the effects of formulation on the release rate of alachlor into water and on the dissipation rate in a loamy sand soil. The alachlor release into water was faster for the AT than for the CF. In general, the MEFs protected alachlor from degradation better than the AT and CF, especially on time scales up to $8 \mathrm{~d}$. The increase in herbicide persistence in MEFs has also been observed by other researchers using several other types of microencapsulation techniques and herbicides (Huang and Ahrens, 1991; Nègre et al., 1992; Dowler et al., 1999; Sopeña et al., 2007). After 14 d, alachlor 
EC 10-MICR OSPHERES
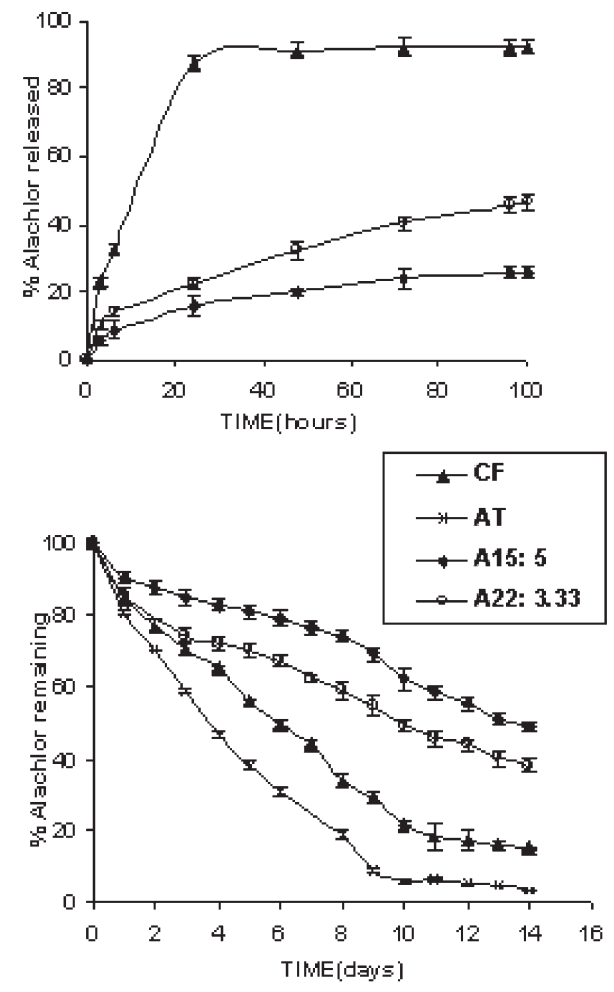

EC 40-MICROSPHERES
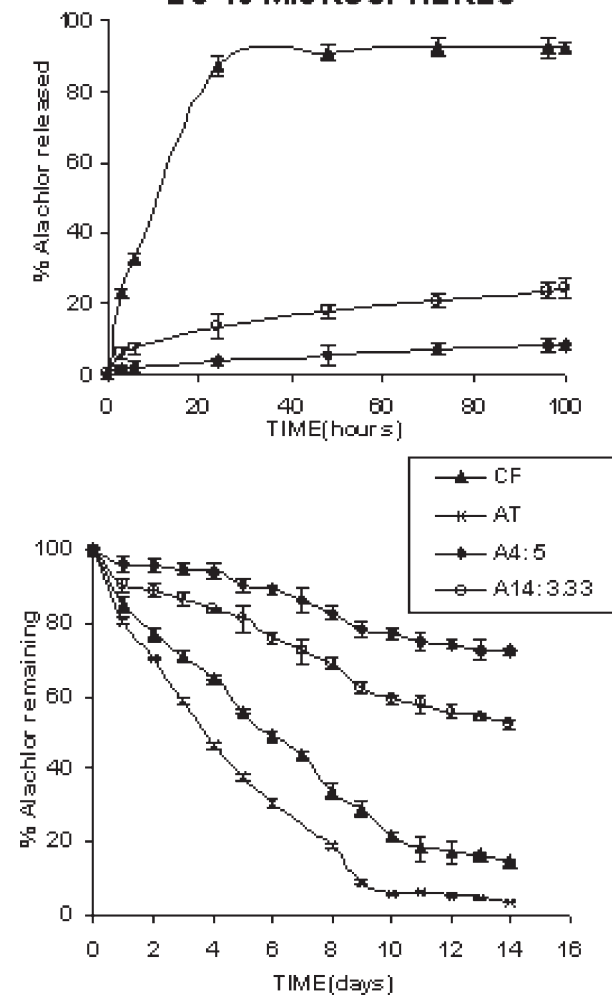

Fig. 1. Influence of ethylcellulose (EC)/herbicide ratio on the percentage of alachlor released into water after $100 \mathrm{~h}$ and remaining in loamy sand soil after $14 \mathrm{~d}$ from ethylcellulose microencapsulated (A4, A14, A15, and A22) and commercial (CF) formulations (AT, alachlor technical grade).

in the AT was degraded more completely than in the CF, in agreement with the findings of Nègre et al. (1992). The degree
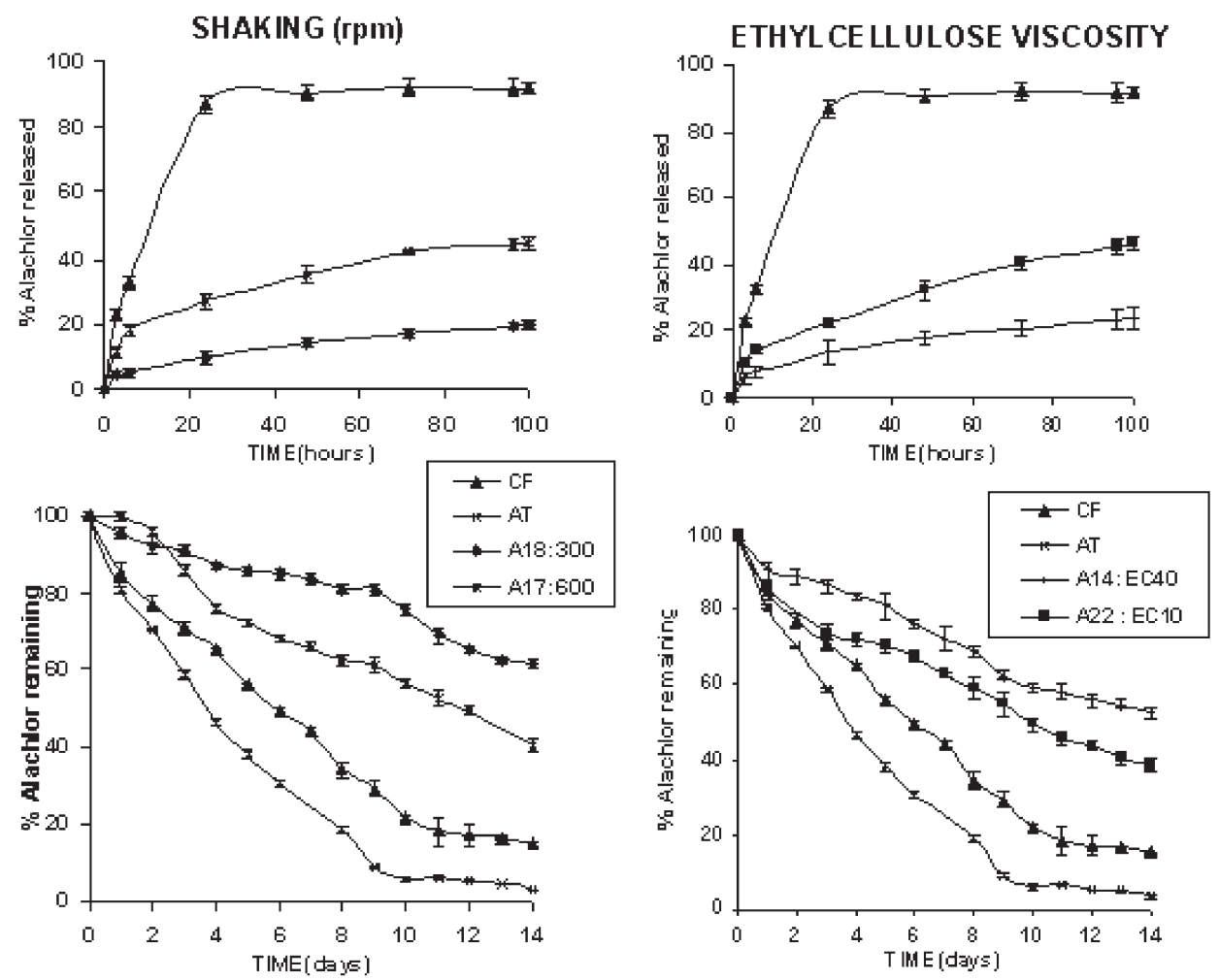

Fig. 2. Influence of shaking speed and type of ethylcellulose on the percentage of alachlor released into water after $100 \mathrm{~h}$ and remained in loamy sand soil after $14 \mathrm{~d}$ from ethylcellulose microencapsulated (A14, A17, A18, A22) and commercial (CF) formulations (AT, alachlor technical grade). of alachlor loss from the MEFs was much less than that from the CF and AT, ranging from 26 to $67 \%$ (Table 3). The results indicate that the composition of the microspheres affects how efficiently they protect the herbicide from degradation (Petersen et al., 1988; Huang and Ahrens, 1991; Nègre et al., 1992). From the percentage of alachlor degradation and $t_{1 / 2}$ values (Table 3), the order of alachlor dissipation rate was found to be $\mathrm{AT}>\mathrm{CF}>\mathrm{A} 8>\mathrm{A} 22 \geq \mathrm{A} 17>\mathrm{A} 15$ $>\mathrm{A} 14>\mathrm{A} 18$, consistent with the rate of alachlor release into water. Therefore, the alachlor release rate into water determined the dissipation rate. As shown in Fig. 2 and 3 , the formulations showing higher alachlor release rates in water (A8, A22, and A17) yielded higher herbicide losses in the soil. In contrast, the slower release rate of alachlor into water for A14 and A18 (Fig. 2) resulted in a significant persistence of alachlor in the soil compared with the CF and the other MEFs. Gan et al. (1994) and Sopeña et al. (2007) observed a major persistence of thiobencarb (S-[(4chlorophenyl)methyl] diethylcarbamothioate) and norflurazon [4-chloro-5-(methylamino)-2-[3(trifluoromethyl)phenyl]-3(2H)pyridazinone] in soils treated with CRFs. They attributed the persistence to the gradual release of active ingredient from the CRFs, keeping a part confined in these formulations and thus protected from environmental loss.

Regression analysis of the dissipation rate constant $\left(K, \mathrm{~d}^{-1}\right)$ vs. the percentage of released alachlor in water indicated a strong linear relationship between the two parameters $\left(r^{2}=0.97\right)$. Therefore, factors such as polymer viscosity, stirring speed, or percentage of some formulation components, such as PVA or PEG, can indirectly influence alachlor dissipation through their effects on herbicide release rates (FernándezUrrusuno et al., 2000; Sopeña et al., 2005). A lower stirring speed and a higher polymer viscosity lowered herbicide release rates because they resulted in larger microsphere sizes and slower herbicide diffusion through the polymer matrix, respec- 
tively (Sopeña et al., 2005). The addition of PEG, however, enhanced the release of alachlor as a consequence of the increased porosity of the EC matrix (Fernández-Urrusuno et al., 2000; Sopeña et al., 2005). Figure 1 shows that, regardless of the type of EC used, a decrease in the EC/herbicide ratio yielded a larger amount of alachlor release into water and made the herbicide more susceptible to degradation. In contrast, a higher polymer viscosity (A14 vs. A22) and a lower stirring speed during the microencapsulation process (A18 vs. A17) lowered herbicide loss by reducing herbicide bioavailability in the soil solution.

The PEG-containing formulations (A8 and A17) showed a peculiar behavior (Fig. 3). The dissipation of alachlor was slightly slower than in the formulations that did not use PEG (A4 and A15) for the first $3 \mathrm{~d}$, but then the herbicide dissipation in the soil increased with time, especially in the case of EC40-containing microspheres (Fig. 3). Similar behavior was previously observed for norflurazon microspheres, where the PEG effect on herbicide dissipation was greater than that observed here (Sopeña et al., 2007). The fraction of PEG polymer retained during the microsphere formation process is trapped inside the microspheres and may offer some resistance to degradation, protecting the herbicide or delaying its loss in the soil for the first $3 \mathrm{~d}$. After that, the microsphere matrix could become more susceptible to environmental degradation (Sopeña et al., 2007). It has been reported that PEG can be degraded by soil microorganisms (Haines and Alexander, 1975) and can be used to modify the degradation of some pollutants in soil (Vajna de Pava and Battistel, 2005). In the present work, the degradation of alachlor in PEGcontaining microspheres (A8 and A17) could occur in two phases due to the presence of PEG: an initial slow phase of dissipation, followed by a rapid phase of dissipation after $3 \mathrm{~d}$ (Fig. 3). This behavior is similar to that reported by Sopeña et al. (2007) for norflurazon MEFs and by Modelli et al. (2004), who studied the extent and rate of degradation of cellulose fibers in flax (Linum usitatissimum L.) in both the native state and after chemical modification (either acetylation or PEG grafting). These researchers found that, initially, PEG-modified fibers degraded more slowly than did native fibers in soil, but the final extent of biodegradation was the same for modified and unmodified fibers.

Taking these findings into account, it can be concluded that the composition of microspheres influences not only the release rate but also alachlor dissipation in soil. This is consistent with the findings of Meghir (1984), Nègre et al. (1992), and Sopeña et al. (2007), who observed that the differences in polymer characteristics in the microencapsulated formulations were responsible for the increased persistence of parathion-methyl [O,O-dimethyl $O$-(4-nitrophenyl) phosphorothioate], alachlor, and norflurazon.
EC40-MCROSPHERES
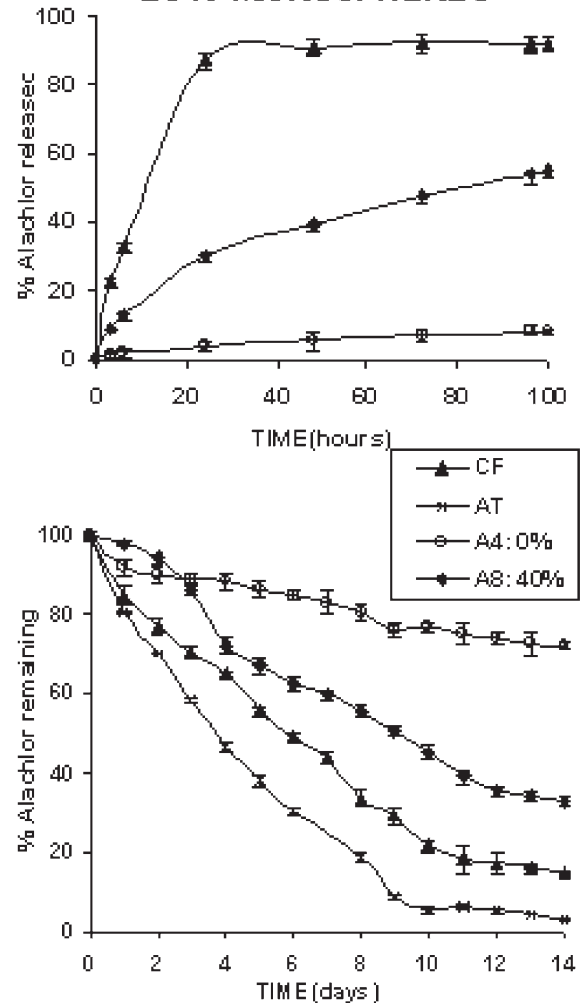

ne percentage of alachlor released into water after $100 \mathrm{~h}$ and remaining in loamy sand soil after $14 \mathrm{~d}$ from ethylcellulose microencapsulated (A4,
$\mathrm{A} 8, \mathrm{~A} 15, \mathrm{~A} 17)$ and commercial (CF) formulations (AT, alachlor technical grade).

The use of formulations A8, A22, or A17 could be advantageous when a high herbicidal activity is necessary in a short period or when rapid dissipation is required to prevent damage to subsequent crops. Formulations A14 and A18 could be advantageous when long-term herbicidal activity is required, avoiding the use of high herbicide application rates that may lead to undesirable economic and environmental consequences. Formulation A4 showed the slowest release rate into water, indicating that the herbicide was more tightly trapped within the EC matrix compared with other MEFs prepared with EC10 (A15) or with a lower EC/A ratio (A14). Herbicide diffusion through the polymer matrix in formulation A4 is more difficult due to its higher viscosity (Assimopoulou and Papageorgiou, 2004) and the lengthening of the diffusional pathway (Sopeña et al., 2005). This suggests that alachlor in A4 would not be sufficiently available in the soil solution to produce an adequate biological effect, as observed in previous studies based on a CRF of norflurazon (Sopeña et al., 2007), and of alachlor and metribuzin [4-amino-6-(1,1-dimethylethyl)-3-(methylthio)1,2,4-triazin-5(4H)-one] (Fleming et al., 1992). Together, these findings suggest that the persistence of alachlor from the A4 formulation $\left(t_{1 / 2}=32.5 \mathrm{~d}\right)$ may be too high to effect weed control within a short period after application.

\section{Influence of Soil Characteristics on Dissipation of Alachlor from Different Ethylcellulose Microencapsulated Formulations}

Based on the results of the previous experiments, two MEFs showing high herbicide persistence (A14 and A18) were selected; A22 was also tested, since except for its EC viscosity, its composi- 


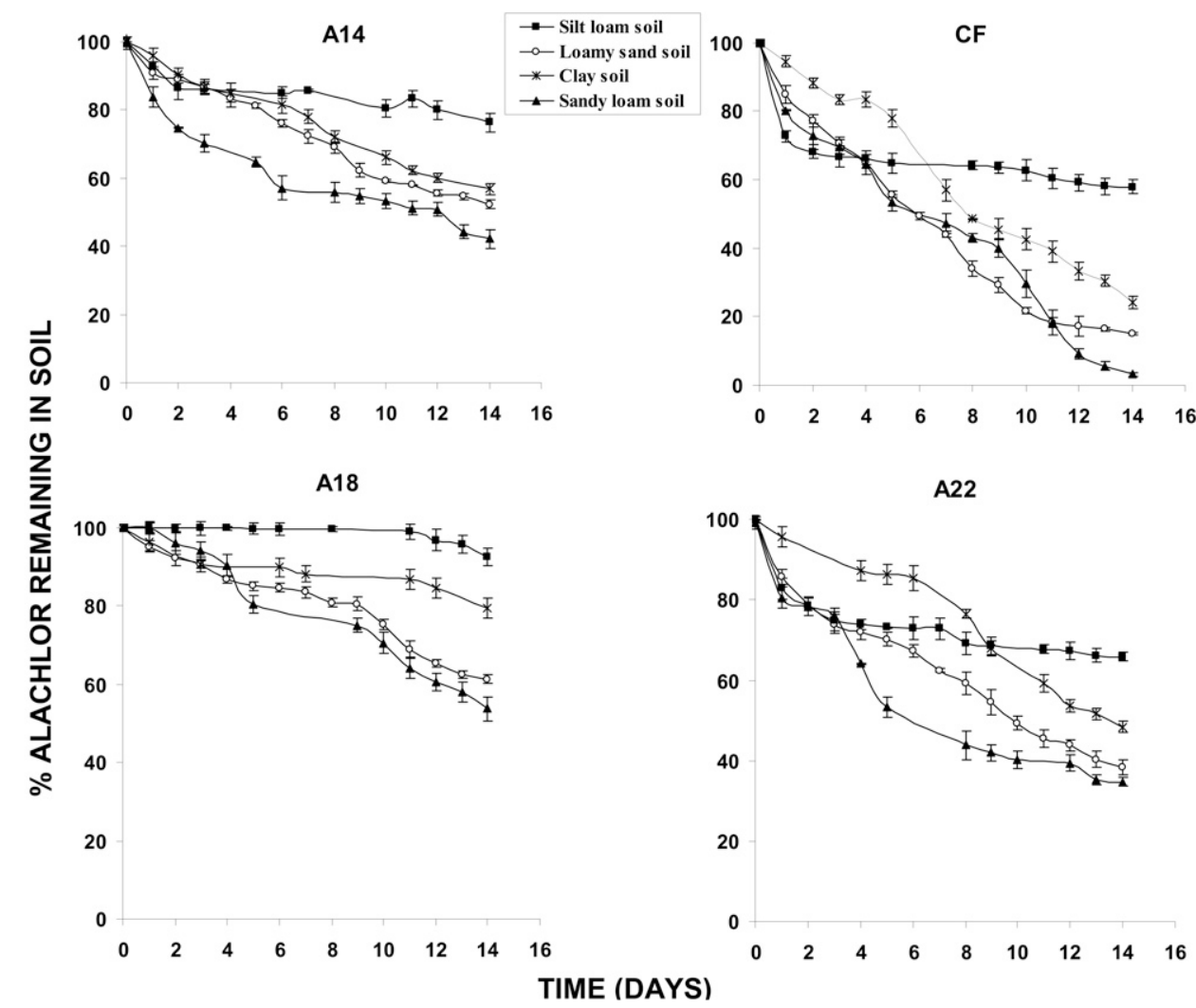

Fig. 4. Alachlor dissipation from ethylcellulose microencapsulated (A14, A18, A22) and commercial (CF) formulations in different soils.

tion is the same as A14 (A22 uses EC10 instead of EC40, thereby allowing a more rapid alachlor release rate). These experiments studied the influence of microsphere composition and soil characteristics on alachlor dissipation relative to that of the CF.

Overall, alachlor applied as MEFs dissipated more slowly than the CF did, regardless of the soil type (Fig. 4). As shown in Table 4, the order of alachlor dissipation rates was $\mathrm{CF}>\mathrm{A} 22$ $>\mathrm{A} 14>\mathrm{A} 18$, the same as for the rate of alachlor release in water

Table 4. Alachlor degraded after $14 \mathrm{~d}$, predicted half-life $\left(t_{1 / 2}\right)$ values ( \pm standard error), degradation constants $(K)$, and coefficients of determination $\left(r^{2}\right)$ for the regression showing alachlor dissipation in different soils treated with a commercial formulation (CF) and ethylcellulose formulations (A22, A14, and A18).

\begin{tabular}{|c|c|c|c|c|c|}
\hline Formulation & soil & $t_{1 / 2}$ & $K$ & $r^{2}$ & $\begin{array}{l}\text { Alachlor } \\
\text { degraded }\end{array}$ \\
\hline & & d & $d^{-1}$ & & $\%$ \\
\hline \multirow[t]{4}{*}{$\mathrm{CF}$} & Sandy loam & $4.58 \pm 0.06$ & 0.151 & 0.94 & 96.7 \\
\hline & Loamy sand & $6.41 \pm 0.10$ & 0.108 & 0.95 & 85.0 \\
\hline & Clay & $7.58 \pm 0.08$ & 0.092 & 0.97 & 71.7 \\
\hline & Silt loam & $42.8 \pm 0.3$ & 0.013 & 0.98 & 42.1 \\
\hline \multirow[t]{4}{*}{ A22 } & Sandy loam & $4.87 \pm 0.02$ & 0.142 & 0.99 & 65.4 \\
\hline & Loamy sand & $11.2 \pm 0.17$ & 0.062 & 0.93 & 61.6 \\
\hline & Clay & $13.8 \pm 0.05$ & 0.050 & 0.92 & 51.6 \\
\hline & Silt loam & $55.0 \pm 0.12$ & 0.011 & 0.96 & 34.2 \\
\hline \multirow[t]{4}{*}{ A14 } & Sandy loam & $13.1 \pm 0.02$ & 0.053 & 0.94 & 57.8 \\
\hline & Loamy sand & $14.9 \pm 0.1$ & 0.047 & 0.98 & 47.8 \\
\hline & Clay & $15.9 \pm 0.04$ & 0.043 & 0.99 & 43.3 \\
\hline & Silt loam & $83.5 \pm 0.21$ & 0.008 & 0.94 & 23.8 \\
\hline \multirow[t]{4}{*}{ A18 } & Sandy loam & $15.4 \pm 0.12$ & 0.045 & 0.99 & 42.3 \\
\hline & Loamy sand & $15.8 \pm 0.02$ & 0.044 & 0.99 & 38.6 \\
\hline & Clay & $49.2 \pm 0.08$ & 0.014 & 0.96 & 20.4 \\
\hline & Silt loam & $135.9 \pm 0.05$ & 0.005 & 0.93 & 9.46 \\
\hline
\end{tabular}

(Fig. 2). The persistence in soil of alachlor delivered from MEFs is related to their composition and to the rate of alachlor release in water. In all cases, herbicide dissipation in the soils could be fit to first-order kinetics. The $r^{2}$ values ranged from 0.99 to 0.93 . The $t_{1 / 2}$ values for the $\mathrm{CF}$ ranged from $4.6 \mathrm{~d}$ in the sandy loam soil to $42.8 \mathrm{~d}$ in the silt loam soil (Table 4).

Regardless of the type of MEF considered, the order of alachlor dissipation rates in the soils studied was: silt loam < clay < loamy sand < sandy loam (Table 4). This order reflects a direct relationship between degradation rate and soil $\mathrm{pH}$, as herbicide degradation was suppressed at low soil $\mathrm{pH}$ levels. This behavior is consistent with earlier results obtained by other researchers (Nègre et al., 1992; Sethi and Chopra, 1975). Likewise, Jurado-Expósito and Walker (1998) suggested that higher soil $\mathrm{pH}$ may be more favorable to microbial degradation of the herbicide, which is a major pathway of alachlor degradation in soils (Walker et al., 1992; Yen et al., 1994; Gan et al., 1995). In fact, this was confirmed by microbiological analyses of the soils (Table 5). Microbial biomass C did not account for alachlor degradation, as no significant correlation between the values of microbial biomass $\mathrm{C}$ and alachlor dissipation was found $(r=0.089)$. Although a significant relationship between DA and herbicide dissipation was found $(r=0.541$, $P<0.01$ ), it probably resulted from a significant positive correlation between $\mathrm{DA}$ and soil $\mathrm{pH}(r=0.949, P<0.01)$. In the case of the clay and loamy sand soils, which have the same $\mathrm{pH}$ value and similar DA, the greater persistence of alachlor in the former can be explained by additional factors. Stepwise multiple linear regression analysis was used to identify predictive equations for herbicide dissipation based on soil variables to see which variable made a more significant contribution to alachlor dissipation in soil. Table 6 shows the best equation for each formulation based on the value of the $r^{2}$ and the $F$ statistic and its significance $(P)$. Table 7 shows the standardized coefficients of the soil predictors and their significance. The $P$ values of all predictors indicate that they significantly influenced the alachlor degradation in soil at a 95\% confidence level. Regardless of the type of formulation, the results showed that, in general, soil $\mathrm{pH}$ was the most significant variable, followed by clay content and DA. Organic matter (OM) content did not significantly influence alachlor dissipation in soil, probably due to the low OM content of these soils. That clay content would influence alachlor dissipation is quite possible as it strongly influences alachlor adsorption in soils (e.g., Sethi and Chopra, 1975; Peter and Weber, 1985; Walker et al., 1992). Under conditions of low clay content, high DA, or a $\mathrm{pH}$ 
favorable for alachlor degradation, such as in the case of the sandy loam soil, A18 performed better than the CF, A14, or A22 in protecting the herbicide from degradation. The benefit of including PEG in the formulation to reduce herbicide loss is clear.

After $14 \mathrm{~d}$, the order of alachlor dissipation rates in the different soils studied was the same as described above, but alachlor applied as the CF or A22 suffered a lower loss in the clay soil than in the silt loam soil on time scales shorter than 6 or $9 \mathrm{~d}$, respectively (Fig. 4). A possible explanation for these results could be the rapid release of alachlor from A22, and especially the CF, into the soil solution, and its rapid adsorption by the clay soil (Bosetto et al., 1993). It is possible that alachlor degradation was delayed in the first few days until its desorption from the clay soil (Yen et al., 1994). In other words, herbicide degradation would depend on the time required for herbicide desorption. Therefore, for A22 and the CF, the persistence of alachlor in the clay soil during the first days compared with the silt loam soil could be the result of two equilibria: one between the processes of degradation and adsorption and another between the processes of adsorption and desorption from the soil. After a brief period of time, alachlor degradation would become important, which could explain that, after 6 or $9 \mathrm{~d}$, the herbicide concentration in the clay soil rapidly decreased (Fig. 4). This phenomenon did not occur in the silt loam soil due to its low $\mathrm{pH}$, which does not favor the sorption process of alachlor in soil (Sethi and Chopra, 1975; Bosetto et al., 1993). A similar explanation based on the equilibrium between adsorption-degradation processes was given by Guo and Wagenet (1999), who evaluated alachlor degradation in silt loam.

\section{CONCLUSIONS}

The results of this study show that formulations of alachlor microencapsulated in EC provided a prolonged release of the herbicide into the soil solution and protected against its dissipation in soil longer than the CF did. Both effects were strongly dependent on the composition of the formulation. Likewise, regardless of soil type, the order of alachlor dissipation rates in soil coincided with that for the release of alachlor in water, which provided a reasonable prediction of its dissipation in soil. The lowest herbicide losses were observed in the MEF with lower stirring speed or a higher EC viscosity. The formulation containing PEG slightly delayed alachlor degradation for the first $3 \mathrm{~d}$. Therefore, a suitable release and adequate protection against herbicide dissipation in soil could be achieved by modifying the formulation parameters or by combining several types of formulations.

Soil characteristics and microorganisms can moderate the degradation rate of encapsulated alachlor in soils. For all formulations tested, the longest alachlor persistence was observed in the soils with low $\mathrm{pH}$ and high clay content. Moreover, the results also demonstrated that the order of alachlor dissipation rates in the soils was always the same, regardless of the formulation. Overall, the effects of soil and formulation on alachlor dissipation can act independently of one another.

The use of these MEFs is advantageous because the herbicide remains active longer in the soil, thereby avoiding the use of high herbicide application rates and minimizing the risk of environmental contamination.

\section{ACKNOWLEDGMENTS}

Fátima Sopeña acknowledges an investigating contract from Junta de Andalucía. This work was supported by MEC (Spanish Ministry of Education and Science), Research Projects REN2003-01509 and AGL 2005-00164, and by Junta de Andalucía, Project P06-FQM-01909.

Table 6. Multiple regression equations and coefficients of determination $\left(r^{2}\right)$ for the percentage of alachlor degraded (ADD) after $14 \mathrm{~d}$ for the commercial formulation (CF) and ethylcellulose formulations (A14, A18, and A22) as a function of soil variables.

\begin{tabular}{llccc}
\multicolumn{1}{c}{ Formulation } & Linear regression equation & $\boldsymbol{r}^{\mathbf{2}}$ & $\boldsymbol{F}$ \\
\hline $\mathrm{CF}$ & $\mathrm{ADD}=-65.142( \pm 4.253)+18.768( \pm 0.638) \mathrm{pH}-0.02( \pm 0.002) \mathrm{CL}++0.156( \pm 0.038) \mathrm{DA} \neq$ & 0.997 & 835.054 & 0.000 \\
$\mathrm{~A} 14$ & $\mathrm{ADD}=-37.253( \pm 6.817)+10.43( \pm 1.02) \mathrm{pH}-0.010( \pm 0.003) \mathrm{CL}+0.183( \pm 0.061) \mathrm{DA}$ & 0.998 & 119.642 & 0.000 \\
$\mathrm{~A} 18$ & $\mathrm{ADD}=-55.207( \pm 5.282)+12.087( \pm 0.683) \mathrm{pH}-0.032( \pm 0.003) \mathrm{CL}$ & 0.980 & 130.316 & 0.000 \\
$\mathrm{~A} 22$ & $\mathrm{ADD}=-34.768( \pm 3.206)+12.210( \pm 0.414) \mathrm{pH}-0.017( \pm 0.002) \mathrm{CL}$ & 0.991 & 481.442 & 0.000 \\
\hline
\end{tabular}

+ Clay content.

‡ Dehydrogenase activity.

Table 7. Standardized regression coefficients of the predictors in the multiple linear regression analyses for the alachlor commercial formulation (CF) and microencapsulated formulations (A14, A18, and A22).

\begin{tabular}{|c|c|c|c|c|c|c|c|c|c|c|c|c|}
\hline \multirow[b]{2}{*}{ Parameter } & \multicolumn{3}{|c|}{ CF } & \multicolumn{3}{|c|}{ A14 } & \multicolumn{3}{|c|}{ A18 } & \multicolumn{3}{|c|}{ A22 } \\
\hline & $\begin{array}{c}\text { Standardized } \\
\text { coefficient }\end{array}$ & $t$ & $P$ & $\begin{array}{c}\text { Standardized } \\
\text { coefficient }\end{array}$ & $t$ & $\boldsymbol{P}$ & $\begin{array}{c}\text { Standardized } \\
\text { coefficient }\end{array}$ & $t$ & $P$ & $\begin{array}{c}\text { Standardized } \\
\text { coefficient }\end{array}$ & $t$ & $P$ \\
\hline Constant & & -15.317 & 0.000 & & -5.465 & 0.001 & & -10.451 & 0.000 & & -10.845 & 0.000 \\
\hline $\mathrm{pH}$ & 0.863 & 29.429 & 0.000 & 0.783 & 10.204 & 0.000 & 0.838 & 17.699 & 0.000 & 0.945 & 29.460 & 0.000 \\
\hline Clay content & -0.260 & -11.852 & 0.000 & -0.147 & -2.572 & 0.033 & -0.535 & -11.269 & 0.000 & -0.321 & -10.011 & 0.000 \\
\hline Dehydrogenase activity & 0.127 & 4.145 & 0.003 & 0.243 & 3.026 & 0.016 & & & & & & \\
\hline
\end{tabular}




\section{REFERENCES}

Ahrens, W. 1994. Alachlor. p. 9-11. In Herbicide handbook. 7th ed. Weed Sci. Soc. Am., Champaign, IL.

Assimopoulou, A., and V.P. Papageorgiou. 2004. Preparation and release studies of alkannin-containing microcapsules. J. Microencapsul. 21:161-173.

Boparai, H., P. Shea, S. Comfort, and D. Snow. 2006. Dechlorinating chloroacetanilide herbicides by dithionite-treated aquifer sediment and surface soil. Environ. Sci. Technol. 40:3043-3049.

Bosetto, M., P. Arfaioli, and P. Fusi. 1993. Interactions of alachlor with homoionic montmorillonites. Soil Sci. 115:105-113.

Buhler, D.D., W.C. Koskinen, M.M. Schreiber, and J. Gan. 1994. Dissipation of alachlor, metholachlor and atrazine from starch-encapsulated formulations in a sandy soil. Weed Sci. 42:411-417.

Carrizosa, M.J., M.C. Hermosin, W.C. Koskinen, and J. Cornejo. 2003. Use of organosmectites to reduce leaching losses of acidic herbicides. Soil Sci. Soc. Am. J. 67:511-517.

Claver, A., P. Ormad, L. Rodríguez, and J.L. Ovelleiro. 2006. Study of the presence of pesticides in surface waters in the Ebro River basin (Spain). Chemosphere 64:1437-1443.

Dailey, O. 2004. Volatilization of alachlor from polymeric formulations. J. Agric. Food Chem. 54:6742-6746.

Dailey, O., and R. Johnson. 1995. Quantitative analysis of alachlor and atrazine in polymeric microcapsules determined by reverse-phase high performance thin layer chromatography with densitometry. J. Liq. Chromatogr. 18:873-885.

Demolon, A., and D. Leroux. 1952. Guide pour l'Étude Experimental des Sols. Gautier, Paris.

Dowler, C., O. Dailey, and B. Mullinix. 1999. Polymeric microcapsules of alachlor and metholachlor: Preparation and evaluation of controlledrelease properties. J. Agric. Food Chem. 47:2908-2913.

Fernández-Pérez, M., M. Villafranca-Sánchez, F. Flores-Céspedes, and F. GarridoHerrera. 2005. Use of bentonite and activated carbon in controlled release formulations of carbofuran. J. Agric. Food Chem. 53:6697-6709.

Fernández-Urrusuno, R., J. Ginés, and E. Morillo. 2000. Development of controlled release formulations of alachlor in ethylcellulose. J. Microencapsul. 17:331-342.

Fleming, G.F., L.M. Wax, F.W. Simmsons, and A.S. Felsot. 1992. Movement of alachlor and metribuzin from controlled release formulations in a sandy soil. Weed Sci. 40:606-613.

Gan, J., M. Hussain, and M.N. Rathor. 1994. Behavior of an alginate-kaolin based controlled-released formulation of the herbicide thiobencarb in simulated ecosystems. Pestic. Sci. 42:265-272.

Gan, J., W.C. Koskinen, R.L. Becker, and D.D. Buhler. 1995. Soil processes and chemical transport. J. Environ. Qual. 24:1162-1169.

Gee, G., and J.W. Bauder. 1979. Particle-size analysis hydrometer. A simplified method for routine textural analysis and a sensitive test of measurement parameters. Soil Sci. Soc. Am. J. 43:1004-1007.

Gerstl, Z., A. Nasser, and U. Mingelgrin. 1998. Controlled release of pesticides into soils from clay-polymer formulations. J. Agric. Food Chem. 46:3797-3802.

Greene, L.C., P.A. Meyers, J.T. Springer, and P.A. Banks. 1992. Biological evaluation of pesticides released from temperature-responsive microcapsules. J. Agric. Food Chem. 40:2274-2278.

Gregorich, E.G., G. Wen, R.P. Voroney, and Kachanoski. 1990. Calibration of a rapid direct chloroform extraction method for measuring soil microbial biomass C. Soil Biol. Biochem. 22:1009-1011.

Guo, L., and R.J. Wagenet. 1999. Evaluation of alachlor degradation under transport conditions. Soil Sci. Soc. Am. J. 63:443-449.

Haines, J.R., and M. Alexander. 1975. Microbial degradation of polyethylene glycols. Appl. Microbiol. 29:621-625.

Huang, Q.L., and J.F. Ahrens. 1991. Residues of alachlor in soil after application of controlled release and conventional formulations. Bull. Environ. Contam. Toxicol. 47:362-367.

Johnson, R.M., and A.B. Pepperman. 1996. Leaching of alachlor from alginateencapsulated controlled-release formulations. Pestic. Sci. 48:157-164.

Jurado-Expósito, M., and A. Walker. 1998. Degradation of isoproturon, propyzamide and alachlor in soil with constant and variable incubation conditions. Weed Res. 38:309-318.

Meghir, S. 1984. Microencapsulation of insecticides by interfacial polycondensation: The benefits and problems. Pestic. Sci. 15:265-267.

Modelli, A., G. Rondinelli, M. Scandola, J. Mergaert, and M.C. Cnockaert. 2004. Biodegradation of chemically modofied flax fibers in soil and in vitro with selected bacteria. Biomacromolecules 5:596-602.

Mueller, T.C., D.R. Shaw, and W.W. Witt. 1999. Relative dissipation of acetochlor, alachlor, metholachlor, and SAN582 from three surface soils. Weed Technol. 13:341-346.

Nègre, M., M. Gennari, E. Raimomndo, L. Celi, M. Trevisan, and E. Capri. 1992. Alachlor dissipation in soil as influenced by formulation in soil moisture. J. Agric. Food Chem. 40:1071-1075.

Peter, J.C., and J.B. Weber. 1985. Adsorption, mobility and efficacy of alachlor and metolachlor as influenced by soil properties. Weed Sci. 33:874-881.

Petersen, B.B., P.J. Shea, and G.A. Wicks. 1988. Acetanilide activity and dissipation as influenced by formulation and wheat stubble. Weed Sci. 36:243-249.

Riggle, B.D., and D. Penner. 1988. Controlled release of three herbicides with the kroft lignin PC940C. Weed Sci. 36:131-136.

Schwab, A., P. Splichal, and M. Banks. 2006. Persistence of atrazine and alachlor in ground water aquifers and soil. Water Air Soil Pollut. 171:203-235.

Selim, H.M., L. Zhou, and S.K. Sue. 2002. Alachlor transport during transient water flow in unsaturated soils. Soil Sci. Soc. Am. J. 66:1773-1783.

Sethi, R.K., and S.L. Chopra. 1975. Adsorption, degradation and leaching of alachlor in some soils. J. Indian Soc. Soil Sci. 23:184-194.

Soil Survey Staff. 2006. Keys to Soil Taxonomy.10th ed. NRCS, Washington, DC.

Sopeña, F., A. Cabrera, C. Maqueda, and E. Morillo. 2005. Controlled release of the herbicide norflurazon into water from ethylcellulose. J. Agric. Food Chem. 53:3540-3547.

Sopeña, F., C. Maqueda, and E. Morillo. 2007. Norflurazon mobility, dissipation, activity and persistence in a sandy soil as influenced by formulation. J. Agric. Food Chem. 55:3561-3567.

USEPA. 1998.: Alachlor. Pesticides fact sheet 63. Office of Pesticides and Toxic Substances, USEPA, Washington, DC.

Undabeytia, T., Y.G. Mishael, S. Nir, B. Papahadjopoulos-Sternberg, B. Rubin, E. Morillo, and C. Maqueda. 2003. Novel system for reducing leaching from formulations of anionic herbicides: Clay-liposomes. Environ. Sci. Technol. 19:4475-4480.

Vajna de Pava, E., and E. Battistel. 2005. Polychlorinated dibenzo-dioxins and -furans detoxification of soil promoted by k-polyethylene glycol technology. Chemosphere 59:1333-1342.

Vasilakoglou, I.B., I.G. Eleftherohorinos, and K.D. Dhima. 2001. Activity, adsorption and mobility of three acetanilide and two new amide herbicides. Weed Res. 41:535-546.

Walker, A., Y.H. Moon, and S. Welch. 1992. Influence of temperature, soil moisture and soil characteristics on the persistence of alachlor. Pestic. Sci. 35:109-116.

Weed, D., R. Kanwar, C. Cambardella, and T. Moorman. 1998. Alachlor dissipation in shallow cropland soil. J. Environ. Qual. 27:767-776.

Wienhold, B.J., and T. Gish. 1994. Chemical properties influencing rate of release of starch encapsulated herbicides: Implications for modifying environmental fate. Chemosphere 28:1035-1046.

Yen, P., W. Koskinen, and E. Schweizer. 1994. Dissipation of alachlor in four soils as influenced by degradation and sorption processes. Weed Sci. 42:233-240. 